\title{
The Development of Kato Nan Ampek Picture Storybook Models Through Literacy of Minangkabau Culture to Develop the Character During Early Childhood
}

\author{
Syamsuarni ${ }^{1}$ and Delfi Eliza ${ }^{2}$ \\ ${ }^{1}$ Student of Early Childhood Education Department, Padang State University, Padang, Indonesia, \\ syamsuarniani@gmail.com \\ ${ }^{2}$ Lecturer of Early Childhood Education Department, Padang State University, Padang, Indonesia, \\ delizazarni@gmail.com
}

\begin{abstract}
This study aims to develop a model of picture books through literacy ampek kato nan Minangkabau culture to develop character early childhood. This story book development through literacy Minangkabau culture to develop the character of children aged 5-6 years. This type of research is the research and development (Research and Development), with model Brog and Gall. The result of the development of kato nan ampek story book contains local cultural values Minangkabau subjects related charge based on the rules of manners/ethics in communication which is known as Kato nan ampek. Judging from the results of this study by the validation test was obtained on average $92.96 \% .77 .79 \%$ teachers' questionnaire responses, the value of characters that appear in $90 \%$ of children. Based on the results of the research it can be concluded that the development of models of kato nan ampek storybook characters to develop early childhood is very valid
\end{abstract}

Keywords — picture books, kato nan ampek, character, early childhood

\section{INTRODUCTION}

Minangkabau as one part of the Malay culture, is a region rich in cultural tradition. One of the Minangkabau culture are intimately known as "Kato nan ampek" or "kato nan ampek" means that people are guided by the four words that manurun, Mandaki, Malereang, and Mandhata in everyday behave. These four words are very influential for the Minangkabau, but the times and technology make some people especially the younger generation lacks courtesy, this is caused by lack of knowledge of children about their own culture. Therefore, this study is very important for the younger generation continue to be able to preserve the Minangkabau culture.

Building character through Children's Literature by Eliza (2017), was an attempt to create reading material of children can develop early childhood character. In this study will be developed kato nan ampek storybook for children aimed at how storybook kato nan ampek can develop a child's character. In this story book children will learn many concepts, consciously or unconsciously, the child will learn and are influenced by each pages of a book that was read or they read.

Research and development being done is to produce a model in the form of picture books through literacy Kato Nan Ampek Minangkabau culture to develop the character of children aged 5-6 years.

\section{LITERATURE REVIEW}

Characteristics include early childhood narrative thinking, and have a high curiosity. One of the activities that they enjoy is listening to a story or a fairy tale. Child's world is the world that should be filled with activities to play, listen to stories, and singing. Telling stories or fairy tales are very attractive to children which impact directly on yourself, (Guna, 2014)

Character is the policy of (goodnes), in the sense of thinking well (thingking), gentle (feeling good), and behave well (behaving good), so the character will appear on the thoughts, feelings, actions of humans (Budiansyah in Hidayati, 2016: 55). If we look at today's children are less familiar with how indigenous Minangkabau culture. How is customary in speaking or saying polite to parents, to teachers at the school, to the brother, to the new people in the know.

Character is the policy of (goodness), in the sense of thinking well (thinking), gentle (feeling good), and behave well (behaving well), so the character will appear on the thoughts, feelings, actions of humans (Budiansyah in Hidayati, 2016: 55). If we look at today's children are less familiar with how indigenous Minangkabau culture. How is customary in speaking or saying polite to parents, to teachers at the school, to the brother, to the new people in the know.

The formation of character in children is one of the goals of the national education system. Article 1 of the 
National Education Act of 2003 states that: among the objectives of national education is to develop the potential of learners to have the intelligence, personality and noble character.

The mandate of the National Education System in 2003 that the goal is that education is not only the human form Indonesia intelligent and knowledgeable, but also personality or character, which in turn will be born generation of people who grew and developed with the characters breathe the noble values of the culture and customs a place where they take shelter, for example, noble values and cultures of indigenous Minangkabau.

\section{RESEARCH METHODOLOGY}

This type of research is research development or Research and Development (R \& D). Research development according to Brog \& Gall (2003) is a process used to develop and validate the educational product. This study follows the steps in the cycle.

Step-by-step development research is happening on the study of the findings of research products that will be developed, products based on these findings, conduct field trials in accordance with the setting in which the product will be used, and to revise the results of field tests (Setyosari, 2010: 194).

Research and development being done is to produce a model in the form of picture books through literacy Kato Nan Ampek Minangkabau culture to develop the character of children aged 5-6 years.

\section{RESULT AND DISCUSSION}

Results of research on the development model of picture books through literacy Kato Nan Ampek Minangkabau culture to develop the character of children aged 5-6 years with the development model Broog and Goal. Description of the results of the study were divided into eight stages, namely: 1) the potential and problems, 2) data collection, 3) the design of products, 4) design validation, 5) design revisions, 6) product trials, 7) product revision, 8) results revision.

Description of the research data is described as follows: A. Potential and problems

In this study the potential and problems obtained in the field by observation, interview and questionnaire to the kindergarten teachers in sub X Koto Singkarak Solok regency, use picture books that imparts about character values of Minangkabau culture is still rarely used, other than that picture books are in kindergarten yet nobody uses language Minangkabau. Most books in schools is the story books that speak Indonesian. Based on potential and existing problems researchers want to develop a picture book about Kato nan Ampek to develop early childhood characters that can be used by parents and teachers to instill character values Minagkabau cultural communication.

\section{B. Data collection}

Researchers in collecting data through observation, literature review, interviews, and observation, theory about the questionnaire in collecting picture books as teaching materials for young children in developing character. In this study, researchers conducted observations in District $\mathrm{X}$ Koto Singkarak Solok regency, in observation researchers collected data amount used picture books have not varied and yet no one speak Minangkabau.

C. Product design

At this stage the researchers designing products teaching materials in the form of picture books through literacy kato nan Minangkabau culture ampek to develop the character of children aged 5-6 years. In this book the researchers want to introduce to children about the way of communication as taught in Minangkabau culture, known as Kato nan ampek namely: Kato mandaki, manurun Kato, Kato Mandata, and Kato malereang.

These picture books as a medium of learning in early childhood characters develop. In this picture story books are text and images, A4 size and colors that appeal to children. This story book using the character in the story Uncu. Making the story books using Adobe Photo Shop CS6 applications.

\section{Design Validation}

After the initial product of this picture book as a resource in the development of early childhood character, then the products are validated by several experts, namely: expert design drawing / layout of the book, linguists / story content, and expert illustrations.

Validation is done on several aspects: the aspect of design drawings, illustrations aspects and aspects of language of image design / layout of the book has been very The results of the analysis of aspects of image design / layout of the book $91.11 \%$ categorized as very valid.

Table 1. Values of validity storybook Kato Nan Ampek to develop the character of children aged 5-6 years

\begin{tabular}{|c|c|c|c|}
\hline No & $\begin{array}{l}\text { Assessment } \\
\text { criteria }\end{array}$ & $\begin{array}{l}\text { Validity } \\
(\%)\end{array}$ & Category \\
\hline 1 & $\begin{array}{l}\text { Design aspects of } \\
\text { drawing / layout } \\
\text { books }\end{array}$ & $91.11 \%$ & very valid \\
\hline 2 & $\begin{array}{l}\text { Illustrations Aspect } \\
\text { Pictures }\end{array}$ & $96.67 \%$ & very valid \\
\hline 3 & $\begin{array}{l}\text { aspects of } \\
\text { Language }\end{array}$ & $88.89 \%$ & very valid \\
\hline \multicolumn{2}{|r|}{ Total average } & $92.22 \%$ & very valid \\
\hline
\end{tabular}

This means that the suitability cover with the content on the book is good. The results also explain that the cover on the book interesting, story content and suitability in the book is easy to understand, has a compelling title so that the general aspects good.

The results of the validation aspects of illustration, obtained yield was $96.67 \%$ which these results have described the suitability of the image, image composition, color image, the image size appropriate for children, images are clear and easy to understand, as well as images and text associated with age children already at a good stage.

Validation of the language obtained yield was $88.89 \%$. This result is certainly considered to be very good because it has good results. Assessment is done with the 9 indicators, which are indicators representing the language, diction, spelling, and sentence used appropriately. With this result 
can be deduced that the language and content of the story, the book is well used for children. Based on the discussion above three aspects in the overall average gained $92.96 \%$ categorized as very valid. Thus story book kato nan ampek display can be tested on children to see the practicality and effectiveness of picture books that have been developed.

A. Picture Story Book Validity Kato nan ampek

The development of picture books kato nan ampek to develop the character of 5-6 years old children can be said valid if it meets the requirements specified. Validation of picture books by three validtor, the experts who are experts in the field of study, among other things: expert image design / layout of the book, an illustration and linguists.

The results of the analysis of aspects of image design / layout of the book $91.11 \%$ categorized as very valid. This means that the suitability cover with the content on the book is good. The results also explain that the cover on the book interesting, story content and suitability in the book is easy to understand, has a compelling title so that the general aspects of image design / layout of the book has been very good.

The results of the validation aspects of illustration, obtained yield was $96.67 \%$ which these results have described the suitability of the image, image composition, color image, the image size appropriate for children, images are clear and easy to understand, as well as images and text associated with age children already at a good stage.

Validation of the language obtained yield was $88.89 \%$. This result is certainly considered to be very good because it has good results. Assessment is done with the 9 indicators, which are indicators representing the language, diction, spelling, and sentence used appropriately. With this result can be deduced that the language and content of the story, the book is well used for children. Based on the discussion above three aspects in the overall average gained $92.96 \%$ categorized as very valid. Thus story book kato nan ampek display can be tested on children to see the practicality and effectiveness of picture books that have been developed.

B. Story Book pictorial practicalities Kato nan ampek

Instead of hitting the practicalities of picture stories kato nan ampek aims to look at the extent to which teachers can understand and use picture books through kato nan ampek Minangkabau literacy culture to develop the character of children aged 5-6 years. Good storybook for children in addition to meet the validity criteria should also be practical means that can be used by teachers and parents easily.

Based on Table 2 above shows that of the seven indicators practicalities assessed by the teacher showed an average yield of the overall assessment of the practicalities of teacher assessment against storybook is $77.75 \%$ with a practical category. It can be concluded that the practicalities of picture books kato nan ampek based on questionner practical categorized teacher assessment.

C. Test the effectiveness of a storybook

To determine the effectiveness of picture books kato nan ampek can be seen from the sheet values of Minangkabau culture literacy, Minangkabau cultural values and the values of the characters are developed using storybooks kato nan ampek assessed by the teacher can be seen in the following table:
Table 2. Test the effectiveness

\begin{tabular}{|l|l|c|c|}
\hline No & \multicolumn{1}{|c|}{ Indicator } & $\begin{array}{c}\text { Practicality } \\
\text { Percentage } \\
(\%)\end{array}$ & Category \\
\hline 1 & $\begin{array}{l}\text { Storybook allows teachers } \\
\text { to teach kato nan ampek }\end{array}$ & $74.29 \%$ & Practical \\
\hline $\mathbf{2}$ & $\begin{array}{l}\text { This story book can } \\
\text { support teachers in } \\
\text { teaching character in } \\
\text { children }\end{array}$ & $75.71 \%$ & Practical \\
\hline $\mathbf{3}$ & $\begin{array}{l}\text { Illustrations in books } \\
\text { allows teachers to teach } \\
\text { kato nan ampek, to } \\
\text { develop character }\end{array}$ & $77.14 \%$ & Practical \\
\hline $\mathbf{4}$ & $\begin{array}{l}\text { Illustrations appropriate } \\
\text { placement in accordance } \\
\text { with the order of the story }\end{array}$ & $74.29 \%$ & Practical \\
\hline $\mathbf{5}$ & $\begin{array}{l}\text { The language used in the } \\
\text { books used in the book is } \\
\text { easy to understand } \\
\text { teachers' stories }\end{array}$ & $81.43 \%$ & Practical \\
\hline $\mathbf{6}$ & $\begin{array}{l}\text { Presentation easily } \\
\text { understood sentences }\end{array}$ & $81.43 \%$ & $\begin{array}{c}\text { very } \\
\text { Practical }\end{array}$ \\
\hline $\mathbf{7}$ & $\begin{array}{l}\text { The use of books in the } \\
\text { time available }\end{array}$ & $80.00 \%$ & Practical \\
\hline \multicolumn{2}{|c|}{ Average } & $\mathbf{7 7 . 7 5 \%}$ & Practical \\
\hline
\end{tabular}

Table 3. Test the effectiveness

\begin{tabular}{|c|l|c|c|}
\hline No & \multicolumn{1}{|c|}{ Indicator } & $\begin{array}{c}\text { Percentag } \\
\text { e (\%) }\end{array}$ & $\begin{array}{l}\text { Categor } \\
\text { y }\end{array}$ \\
\hline 1 & $\begin{array}{l}\text { Child interested in } \\
\text { books }\end{array}$ & 85.98 & $\begin{array}{c}\text { Very } \\
\text { effective }\end{array}$ \\
\hline 2 & $\begin{array}{l}\text { Kids can understand } \\
\text { stories }\end{array}$ & 84.39 & $\begin{array}{c}\text { Very } \\
\text { effective }\end{array}$ \\
\hline 3 & $\begin{array}{l}\text { Kids can use the } \\
\text { language in books }\end{array}$ & 83.96 & $\begin{array}{c}\text { Very } \\
\text { effective }\end{array}$ \\
\hline 4 & $\begin{array}{l}\text { The child can } \\
\text { understand the language } \\
\text { in books }\end{array}$ & 83.96 & $\begin{array}{c}\text { Very } \\
\text { effective }\end{array}$ \\
\hline 5 & $\begin{array}{l}\text { The child can } \\
\text { understand the } \\
\text { vocabulary in books }\end{array}$ & 79.54 & $\begin{array}{c}\text { Very } \\
\text { effective }\end{array}$ \\
\hline 6 & $\begin{array}{l}\text { Kids can read images } \\
\text { which explains Kato }\end{array}$ & 83.18 & $\begin{array}{c}\text { Very } \\
\text { effective }\end{array}$ \\
\hline 7 & $\begin{array}{l}\text { Kids can read images } \\
\text { which explains Kato } \\
\text { Mandata }\end{array}$ & 83.33 & $\begin{array}{c}\text { Very } \\
\text { effective }\end{array}$ \\
\hline 8 & $\begin{array}{l}\text { Kids can read images } \\
\text { which explains Kato } \\
\text { manurun }\end{array}$ & 82.40 & $\begin{array}{c}\text { Very } \\
\text { effective }\end{array}$ \\
\hline 9 & $\begin{array}{l}\text { Kids can read images } \\
\text { which explains Kato } \\
\text { malereang }\end{array}$ & 76.96 & $\begin{array}{c}\text { Very } \\
\text { effective } \\
\text { Vhaldren can be cited } \\
\text { about kato nan ampek }\end{array}$ \\
\hline 11 & $\begin{array}{l}\text { The child can repeat the } \\
\text { words of the story }\end{array}$ & 80.72 & $\begin{array}{c}\text { Very } \\
\text { effective }\end{array}$ \\
\hline
\end{tabular}

Based on Table 3 above shows that of the 14 indicators of effectiveness are assessed by teachers showed an average 
yield of the overall assessment of cultural values Minangkabau using storybooks kayo ampek nan was $82.45 \%$ categorized as very effective

Table 4. The values of Minangkabau culture using storybooks kato nan ampek

\begin{tabular}{|r|l|c|l|}
\hline No. & \multicolumn{1}{|c|}{ Indicator } & $\begin{array}{c}\text { Percentage } \\
(\%)\end{array}$ & Category \\
\hline 1 & $\begin{array}{l}\text { Children can realize the } \\
\text { image that says Kato } \\
\text { mandaki }\end{array}$ & $68.86 \%$ & Effective \\
\hline 2 & $\begin{array}{l}\text { Children can realize be } \\
\text { the image that says } \\
\text { Kato Mandata }\end{array}$ & $67.56 \%$ & Effective \\
\hline 3 & $\begin{array}{l}\text { Children can realize be } \\
\text { the image that says }\end{array}$ & 67.26 & Effective \\
\hline 4 & $\begin{array}{l}\text { Kato manurun } \\
\text { the image that says } \\
\text { Kato malereang }\end{array}$ & 68.26 & Effective \\
\hline 5 & $\begin{array}{l}\text { Children can be pointed } \\
\text { out Kato mandaki }\end{array}$ & 63.08 & Effective \\
\hline 6 & $\begin{array}{l}\text { Children can be pointed } \\
\text { out Kato Mandhatri }\end{array}$ & 67.76 & Effective \\
\hline 7 & $\begin{array}{l}\text { Children can be pointed } \\
\text { out Kato manurun }\end{array}$ & 67.06 & Effective \\
\hline 8 & $\begin{array}{l}\text { Children can be pointed } \\
\text { out Kato malereang }\end{array}$ & 66.87 & Effective \\
\hline 9 & $\begin{array}{l}\text { Kids can explain the } \\
\text { difference kato nan } \\
\text { ampek }\end{array}$ & $\begin{array}{l}\text { Kids can use in } \\
\text { communicating kato } \\
\text { nan ampek }\end{array}$ & Effective \\
\hline Average & 60.10 & Effective \\
\hline
\end{tabular}

Table 5. The values of the characters are developed through story books kato nan ampek

\begin{tabular}{|c|l|c|c|}
\hline No. & \multicolumn{1}{|c|}{ Indicator } & $\begin{array}{c}\text { Percentage } \\
(\mathbf{\%})\end{array}$ & Category \\
\hline 1 & Patient & 91.07 & Very effective \\
\hline 2 & submissive & 91.07 & Very effective \\
\hline 3 & courageous & 91.07 & Very effective \\
\hline 4 & Gregarious & 98.21 & Very effective \\
\hline 5 & loving & 94.64 & Very effective \\
\hline 6 & Cooperate & 92.86 & Very effective \\
\hline 7 & Mutual help & 92.86 & Very effective \\
\hline 8 & Well & 94.64 & Very effective \\
\hline 9 & Diligent & 82.14 & Very effective \\
\hline 10 & Skilled & 80.36 & Very effective \\
\hline 11 & Polite & 94.64 & Very effective \\
\hline 12 & $\begin{array}{l}\text { To be } \\
\text { responsible }\end{array}$ & 83.93 & Very effective \\
\hline \multicolumn{2}{|l}{ Average } & $\mathbf{9 0 . 6 2 \%}$ & Very effective \\
\hline
\end{tabular}

Based on Table 4 above shows that of the 10 indicators the values of Minangkabau culture using storybook rated by teachers showed an average yield of $65.97 \%$ overall assessment with effective category.
According to the table above shows the effectiveness of the 12 indicators assessed by the teacher showed an average yield of character assessment of students was $90.62 \%$ categorized as very effective.

It can be concluded that the picture books kato nan ampek very effective to develop the character of children aged 5-6 years. Products developed in this study is a story book kato nan ampek to develop the character of children aged 5-6 years. This story book have been tested in kindergarten Kartika 1-60, KB-TK Pertiwi Secretariat of Solok and TK Tunas Bangsa Aur Duri, TKPK3A Sumani Solok District. Products can be said to be successful and the kids are excited to listen to a storybook kato nan ampek in order to develop the character. This is in accordance with the relevant previous research conducted by Eliza (2017) with the title "Wordless and Picture Books on Minangkabau Model Based Development to Build Early Childhood Folklore Character and literacy". Research results are designing books without a word and pictorial story based on folklore Minagkabau as a tool to transfer cultural values to children.

Validation of picture books kato nan ampek conducted by three expert validators skilled in the art, namely: expert design drawing / layout of books, experts illustrations, and linguists. This is in accordance with the opinion Plomp (2010), that can be used to test the validity of the expert opinion (judgment validity). Based on the results of the validation performed by the three validators declared that picture books kato nan ampek obtain validation value on average $92.22 \%$.

The response of teachers to the practicality of the picture book kato nan ampek reached a value of $77.75 \%$ with a practical category. Child's response to the effectiveness of a story book kato nan ampek assessed by teachers of literacy assessment sheet reached a value of $82.45 \%$ with a very effective category, from values of Minangkabau culture reached a value of $65.97 \%$ with effective category, and from the character reaches a value assessment $90.62 \%$ categorized as very effective. It can be concluded that the picture book kato nan ampek very effective to develop the character of children aged 5-6 years.

\section{REFERENCES}

[1] Dantes, N. 2014. Metode Penelitian. Yogyakarta: Andi.

[2] Desyandri, 2018. Nilai-nilai kearifan Lokal Untuk Menumbuhkembangkan Literasi Budaya Di Sekolah Dasar.Sekolah Dasar: kajian Teori dan Praktik pendidikan Tahun 27, Nomor 1, Mei 2018 Hal 1-9

[3] Eliza,D (2018). Pengembangan Model Pembelajaran Karakter Berbasis cerita Tradisional Minangkabau Untuk Anak Usia Dini. Jurnal Pedagogi,3 (3b). 153-163

[4] Eliza,D (2017). Emergent Literacy Based on Wordless picture Book to Introduce Minagkabau 
Cultural Value and Identity for early Childhood

.Internasional Conference of Early childhood

Education (ICECE 2017) Volume 169,

https://doi.org/10.2991/icece-17.2018.73

[5] Fauzul, Asni. ( 2012 ). Membangun Mahasiswa yang Berkarakter Melalui Karya Seni.Jurnal Bahasa dan Seni .Volume 13 No 2 Tahun 2012

Doi:

https://doi,org/10.24036/komposisi,v13i2.3938

[6] Guna, I.G.M.D, 2014. Made Taro Mendongeng dan Bermain Sepanjang Waktu.Yogyakarta: Media Kreative.

[7] Kemendikbud, 2016. Gerakakn Literasi untukTumbuhan Budaya Literasi. Media Komunikasi dan Informasi "Jendela "Pendidikan dan kebudayaan.Jakarta: Kemendikbud

[8] Kemendikbud, 2017. Gerakan literasi nasional:materi Pendukung Literasi Budaya dan kewargaan.Jakarta: Kemendikbud.

[9] Plomp, Treed, (2010) An introduction to Educational Design Research Netherlands Instute For Curiculum development

[10] Ngura, Elizabet, (2018). Pengembangan Media Buku Cerita Bergambar untuk Meningkatkan Kemampuan Bercerita dan Perkembangan Sosial Anak Usia Dini di TK Maria Virgo Kabupaten Ende. Jurnal lmiah Pendidikan Citra Abadi Volume 5 No 1 Maret 2018

[11] Setyosari,Punaji. (2010). Metode Penalitian Pendidikan dan Pengembangn. Jakarta: Kencana

[12] Punaji. (2013). Metode Penelitian Pendidikan dan pengembangan. Jakarta : Prendamedia Group

[13] Sugiyono,2008. Metode Penelitian Pendidikan. Bandung:Alfabeta

[14]----------, 2015. Metode Penelitian \& Pengembangan Research and Development

Bandung: Alfabeta

[15] Suryana,D (2013 ). Pendidikan Anak Usia Dini (Teori dan Praktik Pembelajaran) Padang: UNP Press Padang

[16] Suryana, D (2014). Dasar-dasar Pendidikan TK. Jakarta: Universitas Terbuka.

[17] Sayuti, M. (2005). Tau Jo Nan Ampek (Pengetahuan yang Empat Menurut Ajaran Budaya Alan Minangkabau). Padang: Mega Sari. 